\title{
7. The Unexpected Guest: Food and Hospitality in Contemporary Asian Art
}

\author{
Francis Maravillas
}

In recent times, there has been a growing critical and curatorial interest in the conjunction of food and art. This renewed interest in the alimentary has coincided with a heightened awareness of the ethics and poetics of hospitality that underlie the cosmopolitan imaginings of home and belonging in contemporary art. This paper explores the potential of contemporary art in and from Asia to engender new ways of imagining, engaging and becoming at home in the world through distinctly alimentary practices of 'world-making' that are predicated upon acts of hospitality and dialogue within and across specific geographical locales. In particular, it considers how the recent manifestations of food in contemporary Asian art might evoke alternative and more extensively relational frameworks for understanding home and hospitality in ways that intimate new forms of cosmopolitanism and foreground the tensile connections between the aesthetic, the ethical and the political in an increasingly globalised world.

\section{Alimentary Tracts}

In her account of the alimentary economy of colonial and postcolonial South Asia and its diaspora, the literary theorist Parama Roy describes the 'alimentary tract' as a bodily passage encompassing not just the mouth but also 'skin, sinew and gut', 'olfactory organs and nerve endings', and as a corporeal disposition or 'habitus' that functions as a contact zone wherein questions of identity, difference, desire and responsibility are staged. ${ }^{1}$ Significantly, by figuring the alimentary tract as a somatic circuit and gastro-poetic agent that incorporates as much as differentiates, she implicitly refutes the oft-repeated trope of 'eating the Other' that informs the alimentary order of colonial and postcolonial narratives. ${ }^{2}$ For Roy, the alimentary tract is both a boundary and portal that at once feeds and confounds any neat distinction between self and other. Significantly, it does so by engendering appetites and aversions through a recurrent performance

\footnotetext{
1 Parama Roy, Alimentary Tracts: Appetites, Aversions and the Postcolonial (Durham: Duke University Press, 2010), 7.

2 See bell hooks, 'Eating the Other', Black Looks: Race and Representation (Boston: South End Press, 1992), 21-39.
} 
of ethics wherein the terms of encounter with otherness are negotiated. In this context, the alimentary tract may also be viewed as an ethical terrain and fertile metaphor for the sensuous and gustatory passageways that traverse the territories of food and art, and which potentially enable responsible and imaginative forms of connection with others in the world.

The history of food in art is varied and integral, encompassing numerous embodiments of alimentary practice while inhabiting its tracts in the manner of a symbiotic parasite. One may locate these alimentary tracts within a certain arc of vanguard art, one that extends beyond the representational imagery of food (in traditional still-life tableaux, composite portraits or paintings of aristocratic feasts) towards its non-mimetic (ritualistic, metaphorical and performative) uses by experimental and contemporary artists over the past half century. The landmark survey exhibition, Feast: Radical Hospitality in Contemporary Art (2012), for instance, set out to chronicle the emergence of the artist-orchestrated meal, tracing its roots in the iconoclasms and provocations of the European avantgarde of the early twentieth century (through the art movements of Futurism, Dada and Surrealism), its re-emergence in the conceptual and performancebased work of the 1960s and 1970s (by artists such as Daniel Spoerri, Gordon Matta-Clark, and Suzanne Lacy) and its increasingly ubiquitous appearance in the socially engaged or relational practices of the 1990s through to the present (by artists such as Michael Rakowitz and Rirkrit Tiravanija). ${ }^{3}$ Within such a trajectory, tropes of incorporation, digestion, aversion and purgation abound amidst the evocations of commensality and conviviality, revealing a shared investment in a utopian impulse, a desire to constantly test the limits of the body, and an antipathy towards idealist notions of art and the reified habits of modern living. ${ }^{4}$ These conjunctions of food and art, moreover, enact a radical questioning of the pre-eminence of vision in the hierarchical ordering of the senses, while foregrounding the permeability of the boundaries between subject and object, self and other, art and everyday life.

3 Feast: Radical Hospitality in Contemporary Art, was held at the Smart Museum of Art, Chicago, from February to June 2012. It surveyed the emergence of the artist-orchestrated meal through documentary material and newly commissioned public art projects by over 30 artists and art collectives. Having billed itself as the first comprehensive survey of the history of the artist-orchestrated meal, one may question not just the selectiveness of its scope and the particularity of the trajectory that it chronicles, but also its efforts to canonise - partly via archival documentation - a diverse body of work that has its roots within the discourse of institutional critique, and which is intimately tied to the performative spaces and moments of inter-subjective encounter outside the museum. Other, less ambitious, but no less insightful, explorations of the conjuncture of food and art that extend beyond the representation of comestibles in painting can be found in the Pot Luck: Food and Art exhibition held at the New Art Gallery, Walsall, in 2009, and FEAST! Food in Art exhibition held at the Singapore Art Museum in 2000.

4 See Cecilia Novero, Antidiets of the Avant Garde: From Futurist Cooking to Eat Art (University of Minnesota Press, 2010). 
Significantly, the revival of the alimentary in contemporary art has coincided with the globalisation of both food and art, along with a growing recognition of the confluence of epicurean concerns in the culinary and artistic world. ${ }^{5}$ The emergence of contemporary Asian art onto the global stage has, moreover, expanded the range of alimentary practice across new sensory and semiotic terrains, as well as cultural and geographic territories. Indeed, it is more than just a passing coincidence that food has been a recurring motif in contemporary Asian art, one anchored in the popular valorisation of the alimentary as a vital ingredient of sociality and a quotidian index of identity (variously coded in cultural, gendered and religious ways) in a region deeply marked by multiple colonial and postcolonial histories, and by contemporary processes of globalisation.

The alimentary tracts that course through the art of the region are expansive and manifold. At the most basic level, food is used as a raw material for art-making. Here, the substance, materiality and sensory qualities of food are amplified, as in the aromatic spices and herbs in the late Thai artist Montien Boonma's installations, the edible sculptural landscapes of Chinese artist Song Dong, and the rotting apples and bananas in the installation work of his compatriot $\mathrm{Gu}$ Dexin. Moreover, given its prosaic association with the everyday within particular cultural contexts, it is perhaps not surprising that food is also often figured as a trope of identity and difference, as evinced by the symbolic use of rice as a national staple, commodity and spiritual offering in Singaporean artist Zai Kuning's installations and New York-based Malaysian artist Chee Wang Ng's photography, and by the gendered coding of Thai artist Pinaree Sanpitak's multiflavoured, breast-shaped desserts. Other alimentary explorations of identity and difference include Singaporean artist Tang Da Wu's Tapioca Friendship Project (1995), comprising a series of workshops on the cassava root as a source of sustenance in Singapore during the Japanese occupation in the Second World War, and Sydney-based Singapore-born artist Simryn Gill's Forking Tongues (1992), which features dried red chillies and silver cutlery as indices of particular histories of passage and migration.

5 For an account of the globalisation of food, via its circulation as a commodity in transnational supply chains, and the rise of culinary cosmopolitanism, see David Inglis \& Debra Gimlim, eds, The Globalization of Food (Oxford: Berg, 2009). The globalisation of the artworld - arising from the decentring of metropolitan discourses of art and the emergence of contemporary art from outside Euro-America onto the global stageis now well-documented. See Charlotte Bydler, Global Artworld, Inc: On the Globalization of Contemporary Art, Figura Nova Series, no. 32 (Uppsala University Press, 2004); and, Hans Belting \& Andreas Buddensieg, eds, The Global Art World: Audiences, Markets, Museums (Karlsruhe: Hatje Cantz, 2009). In this context, the participation of Michelin-star chef Ferran Adrià of El Bulli in Roger Buergel's Documenta 12 in 2007involving the consumption of Adrià's conceptual meals by randomly selected guests who were flown from Kassel to his restaurant in Spain (designated as the offsite Pavilion G) - is perhaps an index of the art world's recognition not just of the role of food in mediating aesthetic experience, but also of the artful innovations of avant-garde cuisine. See Roger M. Buergel \& Ruth Noack, 'One Artist', in Food for Thought, Thought for Food, eds Richard Hamilton \& Vincent Todoli (New York: Actar, 2009), 77. 
The evocation of identity and difference closely intertwine with the use of food as a site of place-making. The Melbourne-based Thai artist Vipoo Srivilasa's community-oriented sculptural workshops that were held in Sydney and Bangkok, and Montreal-based Chinese artist Karen Tam's kitsch-like replica of a Chinese-Canadian restaurant are notable examples, tapping into transnational and diasporic vectors of connection to an imagined 'home'. On another level, food and its trappings are elevated to the status of utopian ideals and metaphors of social, political and economic change. Here, the pastoral ideals of communal living and socio-ecological sustainability, as explored in the rice paddies of The Land Foundation in Chiang Mai, Thailand, and Thai artist Sakarin Krue-On's Terraced Rice Fields (2007) in Documenta 12, along with the fantastical images of alimentary excess and decay in London-based Chinese artist Gayle Chong Kwan's Cockaigne (2004) series, are exemplary, as are the cooking utensils and domestic wares in the sculptural installations of Indian artist Subodh Gupta and Chinese artist Zhan Wang.

Significantly, it is the use of food as a site and medium of sociality geared towards interaction and participation that facilitates the enactment of artful modes of hospitality predicated upon dialogue with differently situated others in the world. Notable in this regard are Singaporean artist Amanda Heng's performance Let's Chat (1996) and the interactive installation of her compatriot Matthew Ngui entitled You can order and eat delicious poh-piah (1997), both of which involve the preparation, cooking and eating of food in participatory settings within community and gallery contexts. Here, the use of food as a performance medium orients our attention to the way the act of shared communion or commensality dramatises the already artful and performative qualities of the alimentary. As performance studies scholar Barbara Kirshenblatt-Gimblett has demonstrated, cooking techniques, dining rituals and culinary codes are already highly elaborated and theatrical, 'already larger than life ... already highly charged with meaning and affect. ${ }^{6}$ Food, like performance, is 'an art of the concrete ... alive, fugitive and sensory' ${ }^{7}$ In this way, food and its trappings may be viewed as performance art avant la lettre ${ }^{8}$ - which, like performancebased works, engages the senses through their relationship to the body and to others in the world. As we shall see, it is precisely these performative, relational and sensuous processes of the alimentary that sets the table and the stage for the enactment of an artful hospitality and connectivity through generous and responsible acts of 'world-making'.

6 Barbara Kirshenblatt-Gimblett, 'Playing to the Senses: Food as a Performance Medium', Performance Research 4, no. 1 (1999): 1.

7 Ibid.

8 Ibid., 11. 


\section{Eating Pad Thai and Swikee}

In the early 1990s, pad Thai made its celebrated appearance on the international stage of contemporary art, featuring as le plat du jour in the performance installations of aforementioned Thai artist Tiravanija, for which the dish was cooked and served in makeshift, semi-official exhibition spaces or architectural 'non-spaces' of various galleries. ${ }^{9}$ His cooking performances, however, were less about food as substance and sensuous materiality (such as the amber sheen, fulsome flavour and unmistakably aromatic quality of pad Thai) than occasions aiming to prompt - via the forms of sociality and conviviality they conjurereflection on a series of displacements: the displacement of the sites of artmaking, of the identity of the artist and the public, and of the locations in which art is staged and encountered. Nevertheless, it is worth dwelling on the fact that pad Thai (or more accurately, kway teow pad Thai or Thai-style stirfried rice noodles) has only come to symbolise a quintessential form of 'Thai' cooking in the West - despite its Indo-Chinese origins-largely thanks to the ongoing efforts of the Thai Government to promote the country's food to the rest of the world. ${ }^{10}$ These official efforts to promote what is now a renowned signifier of 'Thai' cuisine in the foodscapes of global cities, belie the nationalist investments in the notion of 'Thai-ness' as a powerful solvent that not only absorbs the ethnic heterogeneity of the nation as its mythical essence, but also renders diversity as such, promoting a no-less mythical plurality. ${ }^{11}$

And yet, it is precisely this entangled social and ethno-culinary history of pad Thai that was elided or displaced in Tiravanija's work in the galleries of SoHo and elsewhere, potentially reducing the work to a readily digestible form of culinary cosmopolitanism wherein the 'exchange and communication about "good living" erases the politics of difference'. ${ }^{12}$ Such an elision thus highlights the need to be more attentive to not just the historical embeddedness of hospitality in modes and relations of power, but also to the question of how the artful enactment of hospitable relations with others involves the translation (as opposed to the mere transfer) of the meaning, valence and sensory order of the alimentary across local and transnational contexts. ${ }^{13}$ This process of translation entails being attuned to the specificities of taste and alimentation as much as the

9 Tiravanija uses the term 'non-space' to refer to the in-between space that is neither in the gallery nor in the street, but suspended between art and everyday life. See Laura Trippi, “'Untitled Artists” Projects by Janine Antoni, Ben Kinmont, Rirkrit Tiravanija', in Eating Culture, eds Ron Schapp \& Brian Seitz (Albany: State University of New York Press, 1998), 132-60.

10 See Alexandra Greeley, 'Finding Pad Thai', Gastronomica: The Journal of Food and Culture 9, no. 1 (2009): 78-82.

11 David Teh, 'Hoong khao blachot maa', in Feast: Radical Hospitality in Contemporary Art, ed. Stephanie Smith (Smart Museum of Art, University of Chicago, 2012), 377-84.

12 Novero, Antidiets of the Avant Garde, 268.

13 For an account of hospitality as historically embedded in relations of power between host and guest, see Stuart Hall \& David Scott, 'Hospitality's Others: A Conversation', in The Unexpected Guest: Art, Writing and 
particular contexts in which commensality takes place. In particular, one needs to be attentive to how the question of not just what one eats, but also how, with whom and where one eats, may bear upon the relational acts of generosity and responsibility towards others in the world.

Whereas Tiravanija's performance installations thematise the site and location of art, without addressing its concrete socio-political and historical determinations, Dutch-born, Indonesian resident artist Mella Jaarsma situates her food performances in relation to the complex history of colonialism in Indonesia and the struggles over identity, culture and belonging that it has spawned so as to highlight both the differences and connectivity they engender. In particular, Jaarsma's work seeks to transform the ways in which audiences and participants view and interact with one another by encouraging them to inhabit the 'skin of the other' so as to experience the discomfort and anxiety, as well as pleasure and intimacy, of that role. Her 1998 performance, Pribumi (meaning 'son of the soil' or indigenous person), ${ }^{14}$ for instance, featured stirfried frog legs or swikee - a Chinese delicacy considered unclean (haram) by local Javanese Muslims - that were cooked and served to passers-by on the street outside the Presidential Palace in Yogyakarta as a way of engendering dialogue about race and identity with differently embodied others. Along with referencing Jaarsma's own complex diasporic relation to the Netherlands ${ }^{15}$ (whose sobriquet is 'Kinkerland', or land of the frogs) and the entanglement of Dutch and Indonesian histories, the cooking and consumption of frog legs highlights the process of incorporating the abject and unfamiliar as a way of inhabiting the 'skin of the other' across lines of racial and religious difference. Hence, by provoking moments of discomfort and dialogue in the presence of the other, Jaarsma's performative interventions provide concrete polemical grounds for reconfiguring one's relationship to others in the world, as well as rethinking the representation of identity in local and transnational contexts inflected by relations of power and hierarchy.

Thinking on Hospitality, eds Sally Tallant \& Paul Domela (London: Art Books, 2012), 291-304. For an account of the processes of transfer and translation of food in cross-cultural contexts, see John Clark, 'Food Stories', Gastronomica: The Journal of Food and Culture 4, no. 2 (2004): 43-50.

14 Staged in the wake of riots that took place in May 1998, during which numerous ethnic Chinese were raped and killed, the performance's title - Pribumi - also refers to the declarations of indigeneity in notes that ethnic Chinese placed on the doors of their homes.

15 For an account of how Jaarsma's complex diasporic position — as a Dutch artist residing in Indonesiahas informed her practice, see Michelle Antoinette, 'Deterritorializing Aesthetics: International Art and its New Cosmopolitanisms, from an Indonesian Perspective', in Cosmopatriots: On Distant Belongings and Close Encounters, eds Edwin Jurriëns \& Jeroen de Kloet (Amsterdam: Rodopi, 2007), 217-26. 


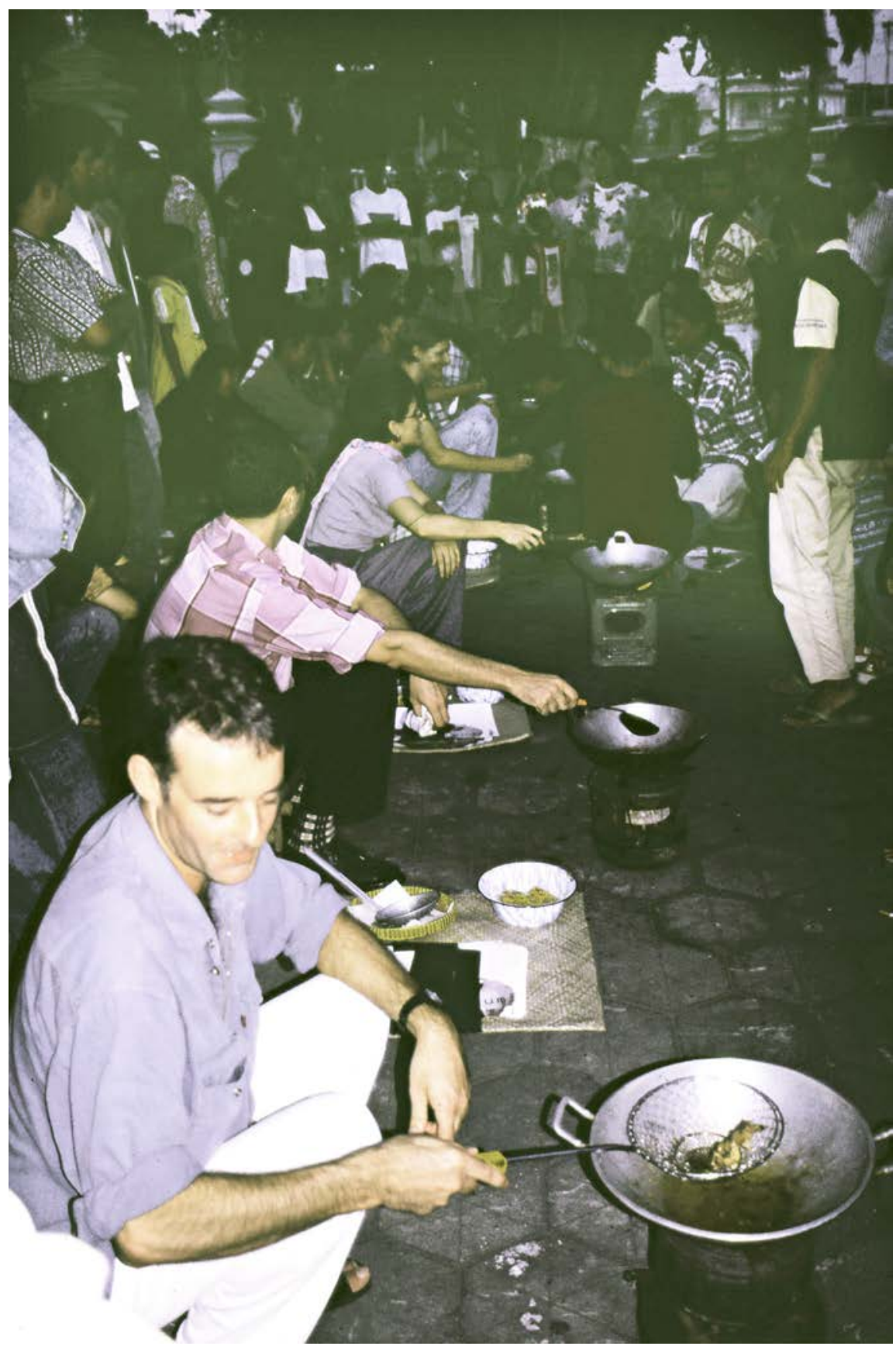

Mella Jaarsma, Pribumi-pribumi 3 July 1998 (performance) Malioboro Street, Yogyakarta; frying frog legs, a Chinese food, by seven Westerners, opening up a dialogue about the racial riots, 1998. 
Significantly, the experience of inhabiting the 'skin of the other' through the exchange and ingestion of food, in Jaarsma's work, renders one's body open to the orchestration of affective intensities, that range from the affordances of vulnerability, discomfort and anxiety to those of carnality and intimacy. Her food performances thus open up a consideration of the body less as a bounded substance or essence, but as an 'interface' that is 'affected, meaning "effectuated," moved, put into motion by other entities, humans or nonhumans'. ${ }^{16}$ The corporeal economy of affect that undergirds Jaarsma's alimentary performance of hospitality is thus not only defined by relations of difference and connectivity to others in the world, but is also shaped by 'encounters with forces and passages of intensity that bear out ... folds of belonging (or non-belonging) to a world' ${ }^{17}$ Her performances can thus be understood as enacting a mode of hospitality that is predicated upon the making of deeply sensuous and affective worlds across often politically charged and socially conflicted contexts that are at once local and transnational.

The contrasting conditions of relationality and exchange in Tiravanija's and Jaarsma's food performances highlights some of the tensions in the debates around relational aesthetics. In his seminal text, Relational Aesthetics (1998), the French curator Nicolas Bourriaud sought to register a shift away from the autonomy of the art object toward notions of process and participatory agency as key to understanding not so much what art means, but what it does. ${ }^{18} \mathrm{He}$ defines relational art as those practices where 'the figures of reference of the sphere of human relations have now become fully-fledged artistic "forms"". ${ }^{19}$ Significantly, Bourriaud contends that relational art nurtures inter-subjective relations that are properly democratic, predicated upon 'negotiations, bonds and co-existences' that are sociable, open-ended and non-hierarchical. ${ }^{20}$ Advocating a more critically engaged account of the politics of participatory art, the art theorist and critic Claire Bishop questions Bourriaud's implicit privileging of a harmonious or emphatic connectivity as the basis of democratic relations over artistic autonomy, antagonism and complexity. ${ }^{21}$ By contrast, Grant Kester and other art theorists argue that ethical engagement is an integral part of collaborative art, wherein the artist must overcome his/her privileged status in order to create an equal dialogue with participants. ${ }^{22}$ At stake in this

16 Bruno Latour, 'How to Talk About the Body? The Normative Dimension of Science Studies', Body and Society 10, no. 2-3 (June 2004): 205.

17 Gregory J. Seigworth \& Melissa Gregg, 'An Inventory of Shimmers', in The Affect Theory Reader, eds M. Gregg \& G.J. Seigworth (Durham and London, Duke University Press, 2010), 3.

18 Nicolas Bourriaud, Relational Aesthetics, trans. Simon Pleasance \& Fronza Woods with M. Copeland (Dijon: Les presses du réel, 2002).

19 Ibid., 28.

20 Ibid., 31, 109.

21 Claire Bishop, ‘Antagonism and Relational Aesthetics', October 110 (Fall 2004): 68.

22 Grant Kester, Conversation Pieces: Community and Communication in Modern Art (Berkeley \& Los Angeles: University of California Press, 2004). 
debate, then, are precisely the kinds of interaction, connectivity and exchange that make up the relational worlds imagined and conjured by art. Moreover, as we shall see, the artful and alimentary practices of 'world-making', borne out of relational acts of commensality and hospitality, not only turn on the question of both ethics and aesthetics; they are also - just like Tiravanija's and Jaarsma's food performances - already embedded within worlds that resonate in different ways across transnational networks of meaning and connection. Indeed, pad Thai, cooked and served in the backroom of a SoHo gallery, is apt to have a markedly different resonance to the same dish cooked and served on the streets of downtown Bangkok. Likewise, swikee cooked and served on the streets of Yogyakarta signifies differently to the same dish consumed as part of a performance enacted during the vernissage of a major international art exhibition in Brisbane. ${ }^{23}$ In this way, both Tiravanija's and Jaarsma's food performances also open up a horizon for thinking about the meaning and intensities of the alimentary within the manifold permutations of commensality and hospitality across non-proximate locales.

Indeed, what tends to be overlooked in the debates about 'relational art' is precisely the scalar dimension of relational connections. How then can we gauge the ways in which such art is generative at different scales, able to produce new modalities of relationality and connectivity - that are imaginative, affective and resonant - in and through the tangle of differences between locales that may be far distant from each other? What are the frameworks for understanding the ligatures of meaning and connection in art which are at once local and transnational? In short, how do we understand art's complex and dynamic relationship with the world at and across a variety of scales?

\section{World-making, Cosmopolitanism and Hospitality}

In his account of contemporary art and the world in which it is made, the art historian and theorist Terry Smith argues that the condition of contemporaneity compels us to grapple with the question of '[h]ow might we think difference and connection at once? [and h]ow might they be conceived so as to capture the complexities of the relationships between them?'24 Smith's concern with the complexity and dynamism of relationality and connectivity within and across difference derives from his contention that the act of 'world-making'

\footnotetext{
23 As part of the Third Asia-Pacific Triennial of Contemporary Art in Brisbane in 1999, Jaarsma enacted her $\mathrm{Hi}$ Inlander performance, which featured people wearing different cloaks made of frog's legs, chicken feet, kangaroo skins or fish skins. Meat from each animal was cooked and served to an international audience as part of the performance.

24 Terry Smith, 'World Picturing in Contemporary Art; Iconogeographic Turning', Australian and New Zealand Journal of Art 6, no. 2 (2005) \& 7, no. 1 (2006): 27.
} 
is constituted by the 'passages of differencing and connecting' ${ }^{25}$ Crucially, this claim rides on a key proposition: that contemporary art is 'essentially, definitively and distinctively worldly'; it is 'from the world' and may well become 'for the world ... the world as it is now and as it might be'. ${ }^{26}$ In this way, the worldliness of contemporary art is not only constituted by the condition of contemporaneity in which it is embedded; it also indexes alternative ways of inhabiting and remaking the world through both difference and connectivity.

Indeed, as key ingredients of the 'contemporary', the condition of worldliness and the agency of 'world-making' can, as art theorist Marsha Meskimmon astutely observes, have a significant role to play in imagining the world otherwise, opening up an ethico-political horizon that seeks to evoke new ways of inhabiting the world, of making worlds within the world. ${ }^{27}$ For Meskimmon, the ethical potential of contemporary art resides in neither a predetermined teleology nor in a set of contractual relations, but rather within an imaginative and affective register 'where the future can be made anew and opened to difference' ${ }^{28}$ Moreover, she locates the ethical agency of art in its capacity to mobilise 'sensory forms of engagement' and tap into 'affective economies of meaning', thereby enabling the emergence of responsible encounters with others in ways that 'makes worlds, rather than mirror them' ${ }^{29}$ Crucially, for Meskimmon, the ethical agency of world-making in art is engendered through a 'cosmopolitan imagination' that is premised upon 'an embodied, embedded, generous and affective form of subjectivity in conversation with others in and through difference'.$^{30}$

It is in the context of the potential conjuncture of art, ethical agency and worldmaking in an open-ended cosmopolitan future that one may fully grasp the ways in which the conjugation of food and art can potentially lay the groundwork for an ethics of the alimentary oriented towards the making of worlds through the enactment of artful modes of hospitality. In an interview in Le Monde, Jacques Derrida evocatively suggests that hospitality is ultimately 'an art and a poetics', even if 'a whole politics depends on it and a whole ethics is determined through it' ${ }^{31}$ At the heart of Derrida's thinking is the paradox of absolute hospitality, wherein the imperative to offer hospitality to others unreservedly is locked in a

\footnotetext{
25 Ibid., 26.

26 Smith, 'Currents of World-Making in Contemporary Art', World Art 1, no. 2 (September 2011): 175.

27 Marsha Meskimmon, 'Making Worlds, Making Subjects: Contemporary Art and the Affective Dimension of Global Ethics', World Art 1, no. 2 (2011): 189-96.

28 Ibid., 191, 193.

29 Ibid., 193-94.

30 Marsha Meskimmon, Contemporary Art and the Cosmopolitan Imagination (London: Routledge, 2010), 6.

31 Jacques Derrida, 'Il n'y a pas de culture ni de lien social sans un principe d'hospitalité', Le Monde, 2 December 1997.
} 
tensile relationship with its conditional form, thereby marking its threshold. ${ }^{32}$ Hospitality cannot thus be defined by a horizon of expectation (as a right or duty regulated by law); rather, it remains an event that arrives unexpectedly from the future: it is a 'hospitality-to-come' (à venir) ${ }^{33}$ and, as such, it must be struggled for inventively and imaginatively. In this context, the art and poetics of hospitality may be understood as one that is enacted in ways that imagine the world anew, opening up an ethico-political horizon that is distinctly cosmopolitan in its diverse and unforeseen encounters with others in the world.

Significantly, the question of hospitality as an artful way of relating to others, of poetically welcoming an unexpected guest (arrivant), is both a condition and an effect of the question of eating and the sharing of food. In an interview with Jean-Luc Nancy, Derrida undertakes to recast the theatre of hospitality by dwelling on the question of 'eating well' (bien manger) as communion, sharing and commensality - for 'one never eats entirely on one's own'. ${ }^{34}$ Eating well is a matter of 'learning and giving to eat, learning-to-give-to-the-other-to-eat', for 'one eats [the other] regardless and lets oneself be eaten by him'. ${ }^{35}$ The question, then, of hospitality turns on the question of what it means to eat well, and to remain responsible to the other with and on whom one dines and to whom one submits to being eaten. In a similar vein, Emmanuel Levinas - to whom Derrida is deeply indebted - restages the question of the alimentary as a profoundly ethical question that lies at the very core of one's being - for 'only the subject that eats can be for-the-other' ${ }^{36}$ For Levinas, the act of eating forms the basis of ethics precisely because our complex alimentary relationship to the world prepares us for an acknowledgement of, and responsibility to, others in the world. ${ }^{37}$ Within this lineage of philosophical thought, the visceral, multisensorial processes of alimentation, gustation and digestion appear as ethical frontiers, as sites for the negotiation of our relation to diverse others in the

\footnotetext{
32 For Derrida, absolute hospitality is one given by a host to a guest, whoever the guest may be, without question and with no expectation of reciprocity. To be the perfect host is to offer hospitality unconditionally and unreservedly. This idealised form of hospitality is impossible because, in practice, hospitality is conditioned or rendered conditional via a calculus of obligation and reciprocity. Absolute or pure hospitality is thus locked in a paradoxical tension with its conditional form, which is offered out of duty or by law, and involves making choices about whom to host, how much to offer or accept, and how long to allow a guest to stay. See Jacques Derrida, Of Hospitality, trans. Rachel Bowlby (Stanford University Press, 2000).

33 Derrida, 'Hospitality', trans. Barry Stocker with Forbes Morlock, Angelaki: Journal of the Theoretical Humanities 5, no. 3 (2000): 14.

34 Derrida, 'Eating Well', in Points: Interviews 1974-1994, ed. Elisabeth Weber and trans. Peggy Kamuf et. al (Stanford University Press, 1995), 282.

35 Ibid.

36 Emmanuel Levinas, Otherwise than Being: Or, Beyond Essence, trans. Alphonso Lingis (Pittsburgh: Duquesne University Press, 1998), 74

37 According to Levinas, "To recognise the other is to recognise a hunger. To recognise the other is to give'. Emmanuel Levinas, Totality and Infinity: An Essay on Exteriority, trans. Alphonso Lingis (Pittsburgh: Duquesne University Press, 1969), 75.
} 
world through our relations with food..$^{38}$ In this way, eating with whom one has welcomed into one's home is the condition for the performative enactment of an artful hospitality, one that opens up a distinctly cosmopolitan space of encounter, signifying the deferment of definite belongings and partaking in the making of responsible worlds.

\section{Making Alimentary Worlds}

\section{Lee Mingwei's The Dining Project}

First presented in 1998 at the Whitney Museum of American Art, New York, as part of the solo exhibition Way Stations, Lee Mingwei's performance installation The Dining Project has since been staged around the world, including as part of the 2012 Feast exhibition in Chicago. In this work, Lee selects individuals by lottery to visit the museum to share a private repast with him, one at a time, after the museum has closed. He then shops for the food and prepares the menu, tailoring it to include his guest's favorite dish. Over dinner the artist engages in conversation with his guest, which is recorded by a video camera placed at table level and played back to museum visitors the next day, so they can gain a sense of what this private meal might be like should they choose to volunteer. In order to ensure the anonymity of his subjects, Lee combines the audiovisual recording of the dialogue with his guests with excerpts of conversations conducted with other people, playing the mixed recording back at a barely audible level during the museum's opening hours. At the Whitney Museum, Lee's guests included a 12-year old girl, a grandmother in her 70s, a tourist from Milwaukee, an editor of pornographic magazines, a Pakistani taxi driver who had been an art historian before coming to New York, and a bulimic who wanted to participate in the work in order to confront her illness. ${ }^{39}$ Notably, many of Lee's dinner companions expressed bewilderment at the ease with which they were able to confide in the artist. ${ }^{40}$

These acts of intimate self-disclosure based on trust highlight the way conversation is an integral part of The Dining Project. This dialogical component is consistent with Lee's longstanding interest in communicative interaction, as

\footnotetext{
38 For a sustained account of Derrida and Levinas' exploration of eating as the frame of reference of ethics, see Sara Guyer, 'Buccal Reading', CR: The New Centennial Review 7, no. 2 (2007): 71-87 and David Goldstein, 'Emmanuel Levinas and the Ontology of Eating', Gastronomica: The Journal of Food and Culture 10, no. 3 (2010): 33-44.

39 Chinese Information and Cultural Centre, 'Service with a Wink at the Whitney', CICC Currents (New York (July/August), 1998), 2, http://web.mit.edu/allanmc/www/leemingwei3.pdf.

40 Charles Yannopoulos, 'Guess Who's Coming to Dinner?', Scene Magazine, 3 June 1999, http://www. clevescene.com/cleveland/guess-whos-coming-to-dinner/Content?oid=1472228.
} 
evinced by his other 'relational' works including The Letter Writing Project (1998), The Sleeping Project (2000), The Living Room Project (2000) and The Mending Project (2009). In The Dining Project, the conversation occurs in the context of the presentation and eating of food, wherein the host and guest enter into a shared communion, performatively enacting hospitality through dialogue and commensality. On one level, Lee's work may be understood as exemplifying the form of practice that Kester refers to as 'dialogical aesthetics' ${ }^{41}$ For Kester, dialogical practices are participatory and interactive, involving conversational exchanges through situational encounters between the artist and the participant that are often performative. ${ }^{42}$ On this basis, he argues that art needs to be viewed as a 'process of communicative exchange rather than a physical object'. And yet, while Lee's work may be viewed as sharing some of the features of 'dialogical aesthetics' through the communicative interactions it stages between the artist and the participant, the quality of these conversations and reciprocal exchanges hinges on the multi-sensorial, material and affective aesthetic of Lee's performance installation.

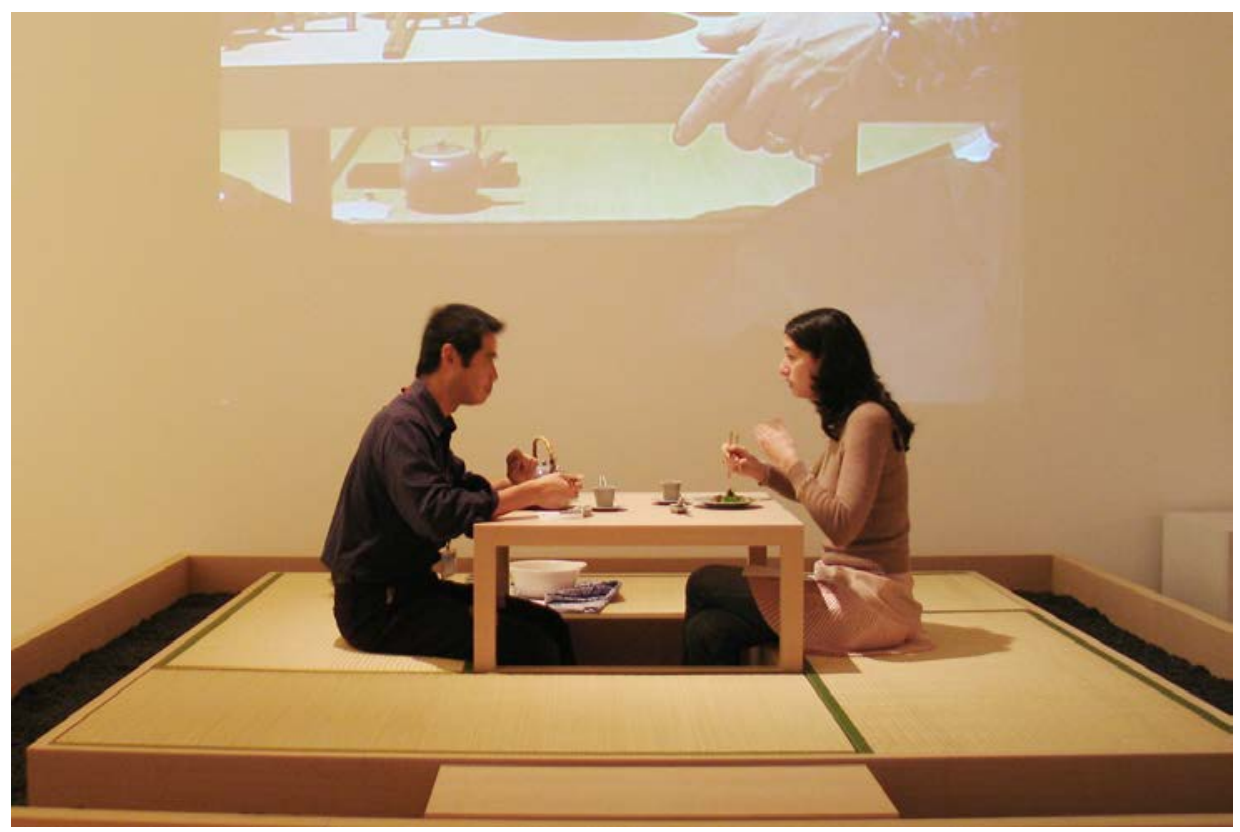

Lee Mingwei, The Dining Project 1997-present; installation view at Mori Art Museum, Tokyo, Japan, 2005; mixed media interactive installation; wood, tatami mats, tableware, beans, projection; 323 x 323 x $85 \mathrm{~cm}$.

Courtesy of the artist and Lombard Freid Gallery, New York (commissioned by Whitney Museum of American Art, New York, 1998); photograph: Lee Studio

41 Kester, Conversation Pieces, 90.

42 Ibid. 
A key component of The Dining Project is the minimalist design and sensuous materiality of the installation itself. Each meal is consumed on a table for two built inside a raised platform consisting of an inner rim of four tatamis (which exude the aroma of the rice straws that form their core), and a hollowed outer rim that is filled with black beans (seeds which signify the start of a conversation and a relationship). The simple yet multi-sensorial design of Lee's installation alludes to the spatiality and sensuality that accompanies the consumption of a meal, and is in keeping with the Zen Buddhist principle that emphasises the paramount importance of the present moment. ${ }^{43}$ Indeed, the quiet apposition of form and substance in the performance of commensality in Lee's work is suggestive of the 'secret architecture of food' ${ }^{44}$ For, like the elegant minimalist platform itself, food and its exchange moves towards the theatrical, enacting a performance on the table and the stage, and thereby becoming an architecture that inhabits the body. In this way Lee's work engenders a gustatory aesthetics marked by the convergence of taste as sensory experience and taste as an aesthetic faculty. As one of his dinner guests observed:

[Lee] had also filled the 'courtyard' with black beans, which provided a massage for our socked feet when we sat at the table. I thought the beans were a lighthearted and fanciful touch, which provided a constant sensory experience throughout the course of the meal. We are so used to the idea of hospitality through our sense of taste, but people rarely think of how hosts attend to the other senses of their guests. ${ }^{45}$

Significantly, for Lee, the sensuous materiality and design of the installation has a bearing on the quality of the conversation over dinner. As he puts it, 'I really could not imagine myself eating on an office table. The conversation would be so different' ${ }^{\prime}{ }^{46}$ In Lee's work then, food and its trappings - the physical and spatial setting of the installation, the occasion and experience of sociality, the presentation of the meal and the dining ritual - engages the senses through their relationship to the body and to the various others with whom an alimentary world is shared. These sensuous, performative and relational processes of the alimentary - along with the architecture of food and commensality-enables Lee to enact an artful hospitality through communion and generosity, one that partakes in the making of shared worlds across difference.

\footnotetext{
43 Lee's installation also recalls the work of the Japanese filmmaker Yasujiro Ozu wherein space, void and stillness are irrevocably tied to form and movement. For an account of the way space defines and instructs form in Ozu's films, see Mark Freeman, 'Kitano's Hana-bi and the Spatial Traditions of Yasujiro Ozu', Senses of Cinema 7 (2000), accessed 15 December 2012, http://sensesofcinema.com/2000/7/asian-cinema/kitano-2/.

44 Jamie Horwitz \& Paulette Singley, eds, Eating Architecture (Massachusetts: MIT Press, 2004), 5.

45 Dory Fox, 'My Dinner with Lee Mingwei', Feast: Radical Hospitality in Contemporary Art (2012), accessed 10 December 2012, https://blogs.uchicago.edu/feast/2012/02/my_dinner_with_lee_mingwei.html 46 Lee Mingwei, The Dining Project, Smart Museum of Art Chicago, accessed 10 December 2012, http://vimeo.com/36285834.
} 


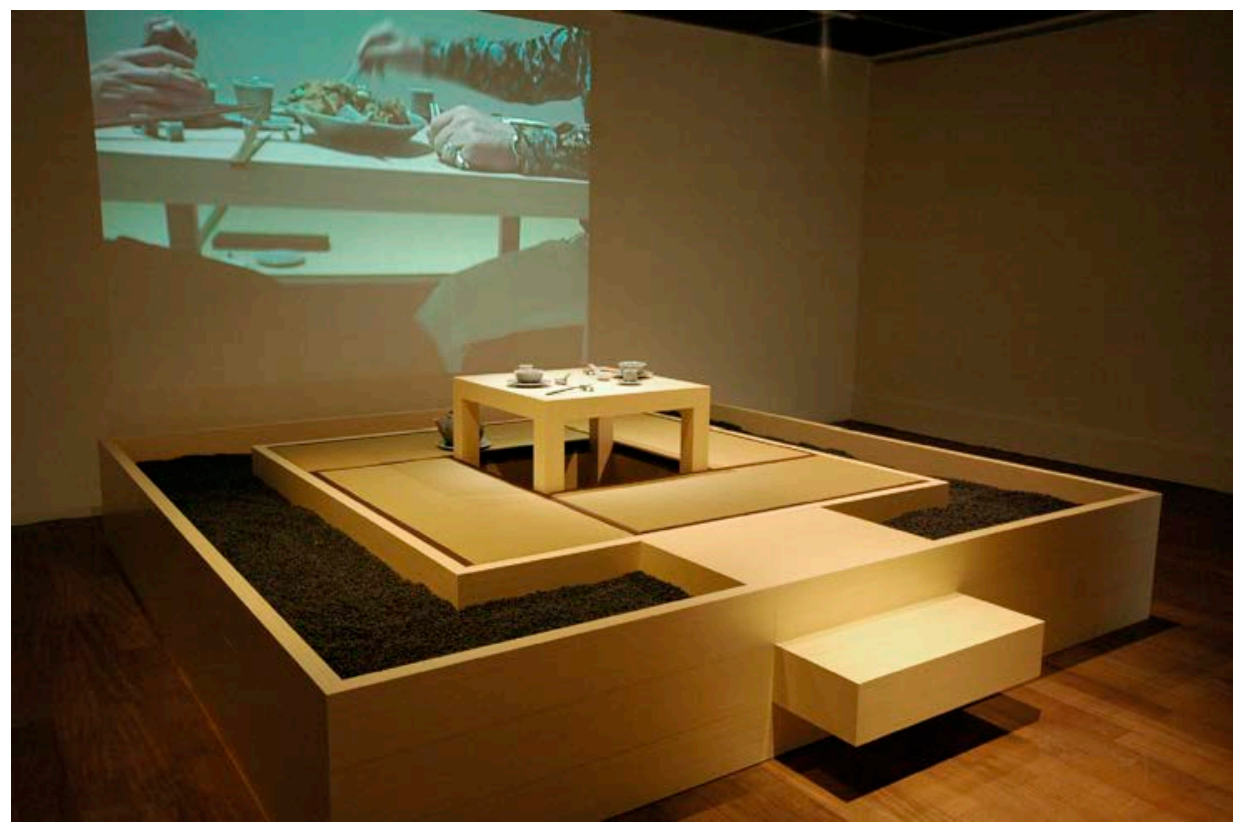

Lee Mingwei, The Dining Project 2007; installation view at Museum of Contemporary Art Taipei (from The Dining Project, 1997-present); mixed media installation; wood, tatami mats, tableware, beans, projection; $323 \times 323 \times 85 \mathrm{~cm}$.

Courtesy of the artist and Lombard-Freid Projects, New York (commissioned by Whitney Museum of American Art, New York, 1998)

\section{Roslisham Ismail's (a.k.a. Ise) Langkasuka Cooking Project}

Commissioned as part of the 7th Asia-Pacific Triennial of Contemporary Art exhibition (2012-2013) at the Queensland Art Gallery and Gallery of Modern Art (QAGOMA) in Brisbane, the Malaysian artist Roslisham Ismail's (a.k.a. Ise) Langkasuka Cooking Project is a collaborative and socially engaged project comprising a cookbook illustrated by the artist, a multimedia installation and a participatory cooking performance. The project was inspired by the artist's travels and interaction with communities across his home state of Kelantan, a culturally rich and politically dynamic region north-east of Malaysia that is renowned for its unique cuisine, one which is strongly influenced by neighbouring Thailand. 


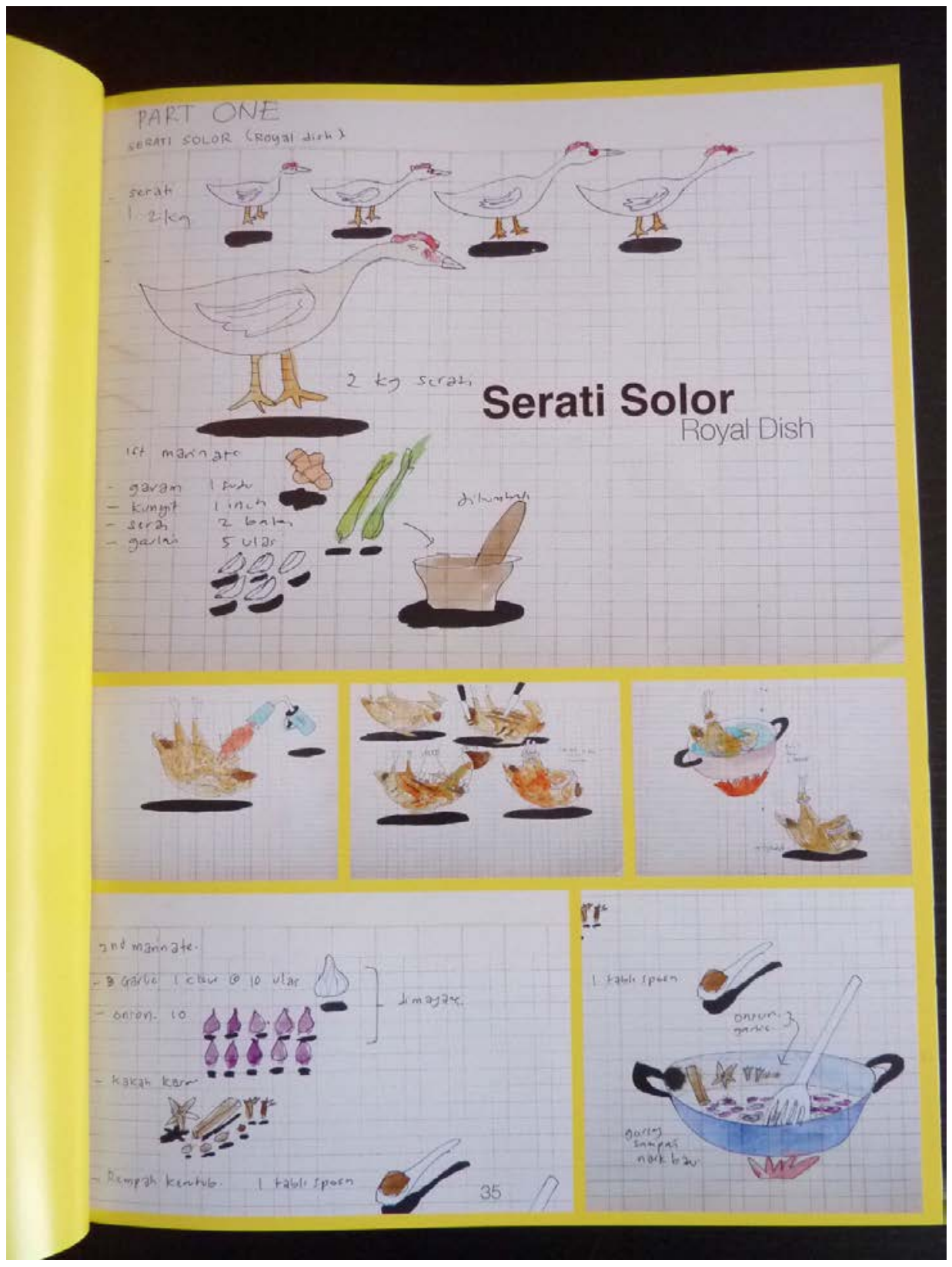

Rolisham Ismail (aka Ise), Langkasuka Cookbook Project 2012-2013; multi-media installation, cookbook and participatory cooking performance commissioned for the '7th Asia-Pacific Triennial of Contemporary Art', Queensland Art Gallery | Gallery of Modern Art (QAGOMA), Brisbane.

Photograph: Francis Maravillas 
Produced as a limited edition publication that is also accessible online, ${ }^{47}$ the Langkasuka Cookbook features vividly illustrated cooking techniques, photographs of local produce markets, stallholders and regional specialties, short essays on the history of Langkasuka as well as recipes from the region's diverse gastronomic heritage that have been drawn from the diverse communities of Kelantan with the help of various collaborators whom Ise refers to as 'superfriends'. Gleaned from Ise's observations and interactions with masterchefs and expert home cooks, including his grandmother and aunt, these recipes include simple popular offerings, such as nasi kerabu (blue rice with salad) and sigang limpa (cow spleen soup), as well as fine cuisine, such as serati solor (a traditional Langkasukan royal dish featuring duck or goose). As both a compendium and a cultural memoir, the significance of Ise's Langkasuka Cookbook stems from both its archival and performative qualities.

In his seminal essay 'An Archival Impulse', art theorist Hal Foster argues that the most notable function of archival art is to 'make historical information, often lost or displaced, physically present' ${ }^{48}$ Significantly, for Foster, the archival impulse in art is not only documentary but also generative in ways that underscore the nature of all archival materials as 'found yet constructed, factual and fictive, public yet private'. ${ }^{49}$ As a repository of embodied memories, Ise's Langkasuka Cookbook stands as a physical document that records a particular version of the taste, textures, smells and flavors of both rare and popular dishes that comprise the region's shared gustatory legacy. As such, the Langkasuka Cookbook is not just a didactic or practical culinary guide; rather, it functions as a sensory archive whose epistemological value stems from its evocation of personal, cultural and historical memories - of places lived, foods eaten, worlds shared and identities formed - through textual and visual devices. In this way, it articulates what cultural anthropologist Jon Holtzman calls a form of 'gustatory nostalgia', whereby the region's diverse food and culinary practice 'offers a potential window into forms of memory that are more heteroglossic, ambivalent, layered and textured'.$^{50}$ Such a nostalgia conveys less a desire to return to a lost home through the memories encoded in food; rather, the sensuous presentation of the region's traditional food is used to connect the past with the present so as to 'go deeper into the layers of who people are'. ${ }^{51}$

\footnotetext{
47 https://www.qagoma.qld.gov.au/exhibitions/past/2012/apt7_asia_pacific_triennial_of_contemporary_ art/artists/roslisham_ismail_ise

48 Hal Foster, 'An Archival Impulse', October 110 (Fall 2004): 4.

49 Ibid., 5.

50 Jon D. Holtzman, 'Food and Memory', Annual Review of Anthropology 35 (2006): 361-78.

51 Roslisham Ismail (Ise), 'An Interview', The 7th Asia-Pacific Triennial of Contemporary Art, exhibition catalogue (Brisbane: Queensland Art Gallery | Gallery of Modern Art, 2012).
} 


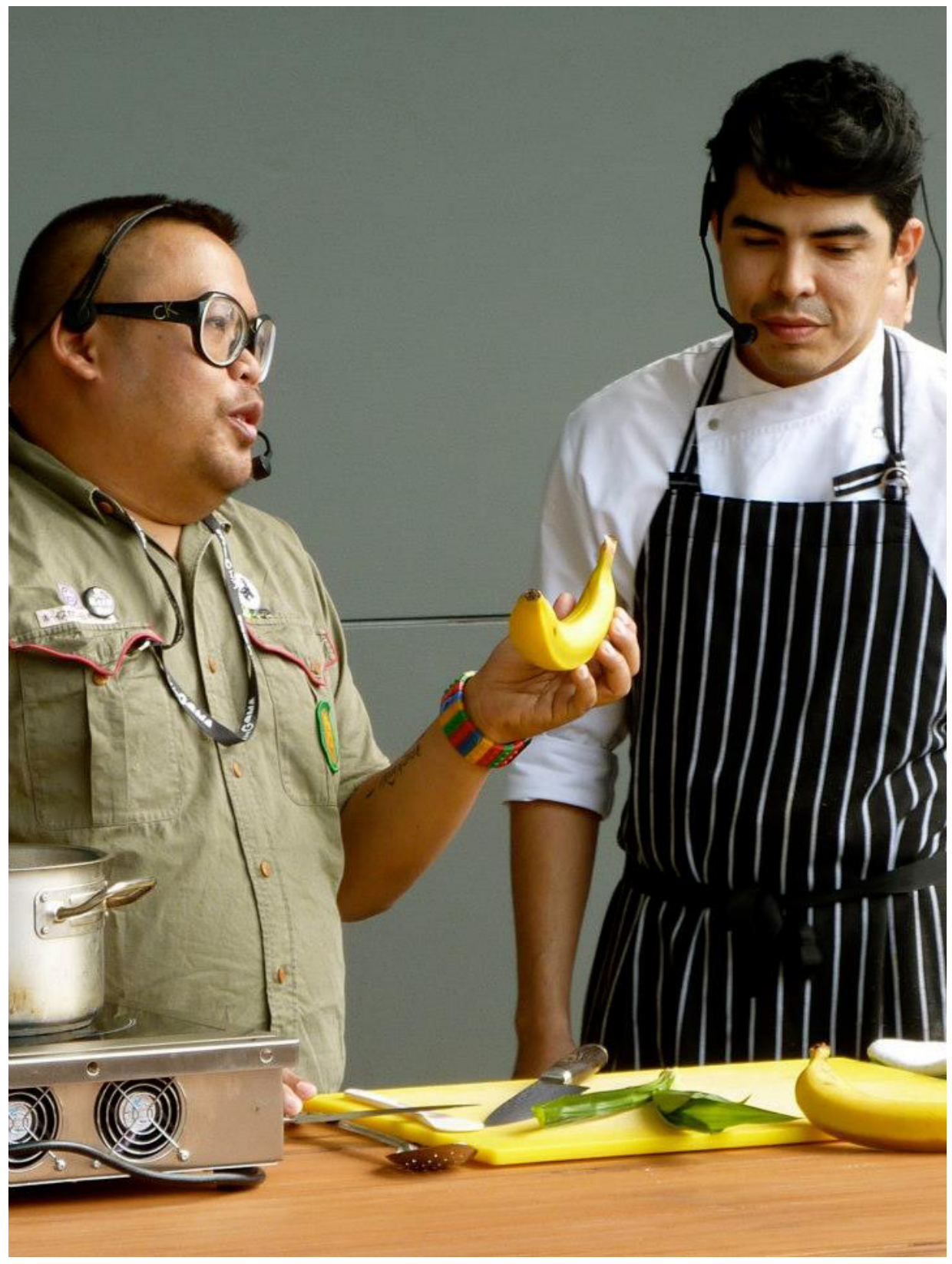

Rolisham Ismail (aka Ise), Langkasuka Cookbook Project, 2012-2013; multi-media installation, cookbook and participatory cooking performance commissioned for the '7th Asia-Pacific Triennial of Contemporary Art', Queensland Art Gallery | Gallery of Modern Art (QAGOMA), Brisbane.

Photograph: Francis Maravillas 
At the same time, the Langkasuka Cookbook may also be understood as exhibiting a performative quality through Ise's simple yet vivid illustrations of the cooking techniques that accompany each recipe. These graphic, comiclike illustrations impart a fictive and actively rhetorical quality that eschews the representational rules of classical mimesis and destabilises the boundaries of art and everyday life, presenting the making and eating of food as an effect of a desire to reconnect with memories of 'home' by creatively re-encoding it in the present. The performative quality of these illustrations is thus reflected in its active and dynamic process of archive-making, one that unsettles the stability of memories encoded within the food documented by the cookbook, while affirming the gaps and openings of the physical document as it enters into circulation and use in a contemporary transnational context. Indeed, while cookbooks provide signposts for cultural reproduction, they cannot contain the embodied practice and experience of what Luce Giard calls 'doing-cooking', 52 whereby the body, memory and the senses work to link past and present, here and elsewhere. The Langkasuka Cookbook's performativity, therefore, also stems from the actual, 'hands-on' preparation, making and consumption of the food it records, which takes places in the public cooking demonstrations performed by Ise as a key component of the project. At QAGOMA, Ise worked alongside staff from GOMA's café, either in the kitchen or outside the gallery, during the Triennial's vernissage, to make, serve and tell stories about sira pisang (sweet glazed bananas with pandan leaves), one of Ise's favourite childhood dishes. While the making of the dish reproduces the taste and textures of 'home', Ise's public demonstrations enact a form of hospitality through the sharing and cultural transmission of embodied memories, thereby engendering a form of sensuous and sensory connectivity with others in the world.

\section{The Ethics and Aesthetics of the Alimentary}

Across these diverse conjunctions of the alimentary and artistic realms, food and its trappings appear as variously sensuous, affective and semiotically charged in ways that confound the boundaries of art's territory, thereby acting as portals for ethico-political engagement with the wider world. In this context, an ethics of the alimentary demands an expanded notion of the senses that encompasses the affective structures of pleasure, intimacy and sociality as much as those of anxiety, discomfort and disdain. As Roy has observed, the grammar of an 'alimentary ethics' orients our attention to the sensuous appetites and aversions

52 Luce Giard, 'Doing Cooking', in The Practice of Everyday Life, vol. 2. Cooking and Living, ed. Michel de Certeau, Luce Giard \& Pierre Mayol (Minneapolis: University of Minnesota Press, 1998). See also Simon Choo, 'Eating Satay Babi: Sensory Perception of Transnational Movement', Journal of Intercultural Studies 25, no. 3 (2004): 210. 
that precede and set the terms for encounters with otherness. ${ }^{53}$ It is an ethics that is predicated on economies of hospitality that confound the boundaries between self and other. It is one, moreover, that is attuned to the 'complex moral structure of embodiment' and is grounded in a somatic engagement with others that is both sensuous and affective. ${ }^{54}$ Significantly, as an affective pedagogy of encounters with others in the world that 'disturbs, opens up and rearranges parts of ourselves', ${ }^{55}$ the ethics of the alimentary is a key locus for the 'precarious' making and remaking of the world in and through art. ${ }^{56}$ The ethical world-making agency of art is thus defined by the horizon of what Jill Bennett refers to as a 'practical aesthetics', one that 'apprehend[s] the world via sense-based and affective processes - processes that touch bodies intimately and directly but that also underpin the emotions, sentiments and passions of public life' ${ }^{57}$ In this context, the sensuous, performative and relational process of the alimentary in contemporary Asian art may be understood as a precondition for the enactment of an artful hospitality through acts of generosity and responsibility that partake in the making of affective and sensuous worlds across difference in a region shaped by the legacy of multiple and overlapping (post-)colonial histories.

\footnotetext{
53 Roy, Alimentary Tracts, 29.

54 Ibid.

55 Elspeth Probyn, Carnal Appetites: Food Sex Identities (New York: Routledge 2000), 70.

56 Marsha Meskimmon, 'The Precarious Ecolologies of Cosmopolitanism', Humanities Research XIX, no. 2 (2013): 39.

57 Jill Bennett, Practical Aesthetics: Events, Affects and Art after 9/11 (London: I.B Tauris 2012), 3.
} 
This text taken from Contemporary Asian Art and Exhibitions: Connectivities and world-making, by Michelle Antoinette and Caroline Turner, published 2014 by ANU Press, The Australian National University, Canberra, Australia. 